\title{
FISH ABUNDANCE AND DISTRIBUTION PATTERNS RELATED TO ENVIRONMENTAL FACTORS IN A CHOKED TEMPERATE COASTAL LAGOON (ARGENTINA)
}

\section{Daniel Osvaldo Bruno ${ }^{1, *}$; Santiago Aldo Barbini ${ }^{2}$; Juan Martín Díaz de Astarloa ${ }^{3}$ and Patricia Martos ${ }^{4}$}

${ }^{1,3}$ Universidad Nacional de Mar del Plata (UNMdP) - Instituto de Investigaciones Marinas y Costeras Laboratorio de Biología Morfológica y Molecular de Peces (B7602AYL, Mar del Plata, AR, CONICET))

${ }^{2}$ Universidad Nacional de Mar del Plata (UNMdP) -Instituto de Investigaciones Marinas y Costeras Laboratorio de Ictiología

(B7602AYL, Mar del Plata, AR, CONICET)

${ }^{4}$ Universidad Nacional de Mar del Plata (UNMdP) - Facultad de Ciencias Exactas y Naturales Departamento de Ciencias Marinas, (B7602AYL, Mar del Plata, AR, INIDEP)

*Corresponding author: dobruno@mdp.edu.ar

\section{A B S T R A C T}

The aim of this study was to assess the influence of environmental factors on the fish distribution and abundance in Mar Chiquita coastal lagoon. Seasonal fish sampling stations were distributed along the lagoon and grouped in three zones from a mixo-oligohaline waters zone with high contribution of freshwater to a mixo-eurihaline waters zone with high marine water influence. A mixo-mesohaline waters zone characterized the middle part of the lagoon. The results showed that the fish composition was dominated by marine estuarine dependent (ED) species in all three zones and in all seasons: Odontesthes argentinensis, Brevoortia aurea, Mugil liza and Micropogonias furnieri were the most representative species. The following important ecological category was freshwater fishes (FW), with Platanichthys platana and Jenynsia multidentata being the most representative species. According to the best model selected, by fitting generalized linear models, abundance of ED increased as water temperature increased during summer and autumn in all three zones. The highest abundance was recorded in the mixo-eurihaline waters zone. On the other hand, FW abundance increased with high rainfall and also when easterly winds blew. In conclusion, a differential habitat use by the species that occur in the Mar Chiquita coastal lagoon was observed. A few ED species dominated the fish composition but FW species also made use of the lagoon during periods of heavy rainfall.

\section{RESUMO}

O objetivo deste estudo foi avaliar a influência de fatores ambientais sobre a distribuição e abundância de peixes na lagoa costeira Mar Chiquita. Estações sazonais de amostragem de peixes foram distribuídas ao longo da lagoa e agrupadas em três zonas de uma zona de águas Mixooligohalino com elevado aporte de água doce para uma zona de águas Mixo-eurihaline com alta influência da água do mar. Uma zona de águas Mixo-mesohalino caracteriza a parte do meio da lagoa. Os resultados mostraram que a composição dos peixes foi dominada por espécies marinhos estuarinos dependentes (ED) em todas as três zonas e em todas as estações: Odontesthes argentinensis, Brevoortia aurea, Mugil liza e Micropogonias furnieri foram as espécies mais representativas. A categoria seguinte mais importante foi peixes de água doce (FW), com Platanichthys platana e Jenynsia multidentata sendo as espécies mais representativas. De acordo com o melhor modelo selecionado pelo ajuste de modelos lineares generalizados, a abundância de ED aumentou de acordo com a temperatura da água durante o verão e outono, em todas as três zonas. A maior abundância foi registrada na zona de águas mixo-eurihalinas. Por outro lado, a abundância de FW aumentou com o aumento da pluviosidade e também quando os ventos de direção leste sopraram. Em conclusão, a utilização diferencial do habitat pelas espécies que ocorrem na lagoa costeira Mar Chiquita foi observada. Poucas espécies ED dominaram a composição de espécies de peixes, enquanto FW fizeram uso da lagoa quando as condições de alta pluviosidade foram observados.

Descriptors: Fish distribution patterns, Estuarine environments, Generalized linear models, Mar Chiquita coastal lagoon.

Descritores: Padrões de distribuição de peixes, Ambientes estuarinos, Modelos lineares generalizados, Lagoa costeira Mar Chiquita. 


\section{INTRODUCTION}

Coastal lagoons are shallow estuarine environments where salt and fresh water interact, the water mass is impounded by some type of sedimentary barrier and the connection with the open sea is restricted to one to several openings (inlets) in the barrier maintained mainly due to the action of tidal currents against the effect of wave-generated longshore currents (ISLA, 1995). In particular, choked coastal lagoons are characterized by the diffuse transport which is the principal process involved in flushing the lagoon (KJERFVE; MAGILL, 1989).

Estuaries and coastal lagoons constitute ecosystems of biological and ecological importance in both tropical (BLABER, 2000) and temperate (ELLIOTT; HEMINGWAY, 2002) habitats. These habitats have high fish productivity (DAY; YÁÑEZ-ARANCIBIA, 1985; COUSSEAU et al., 2001) and play an important role in biological and reproductive cycles of many marine species (GALVÁN-PIÑA et al., 2003). Also these shallow bodies of water are exposed to several physical variations mainly of temperature and salinity (ISLA, 1995), and biological variations such as predation, competition and refuge (GIBSON, 1994), which lead to particular adaptations of the associated ichthyofauna, affecting the distribution of the organisms in these habitats (ELLIOT; HEMINGWAY, 2002).

The relationship between environmental factors and the distribution of organisms within estuarine environments has received considerable attention. Because fish are one of the dominant macro faunal components of estuarine biota, many studies have focused on their distribution patterns (BLABER; BLABER, 1980; MARSHALL; ELLIOTT, 1998; WHITFIELD, 1999; AKIN et al., 2005; SELLESLAGH; AMARA, 2009). Several parameters influence the differential distribution of both the juveniles and adults of fish species. The relative importance of each factor differs according to the species (BLABER; BLABER, 1980). Knowledge and understanding of estuarine habitat use by juveniles is important for the improvement of conservation policies with a view to preserving these ecologically important environments (SELLESLAGH; AMARA, 2009).

The Mar Chiquita coastal lagoon $\left(37^{\circ} 32^{\prime} \mathrm{S}\right.$, $57^{\circ} 19^{\prime} \mathrm{W}$, Argentina; a UNESCO Man and the Biosphere Reserve; UNESCO, 1996) is a $46-\mathrm{km}^{2}$ body of brackish water affected by semidiurnal low amplitude $(<1 \mathrm{~m})$ tides (RETA et al., 2001) and is characterized by mudflats and surrounding marshes dominated by the cordgrass Spartina densiflora (e.g. ISACCH et al., 2006) and the burrowing crab Neohelice granulata (e.g. IRIBARNE et al., 1997). An inlet $6 \mathrm{~km}$ long and $200 \mathrm{~m}$ in width links the lagoon to the ocean (RETA et al., 2001). Sea water inflow depends on the tides and also on wind direction and intensity, the largest inflows have been recorded to occur under the influence of strong southeasterly winds (OLIVIER et al., 1972). Freshwater inflows are due to several artificial channels and streams, of which Vivoratá stream is one of the largest and the only one reaching the inlet of the lagoon (OLIVIER et al., 1972). Temperature and salinity are extremely variable, the latter having a horizontal gradient (RETA et al., 2001; GONZÁLEZ CASTRO et al., 2009). This lagoon acts as a refuge and feeding ground for juvenile fish during their critical development stages, and it is also used by adult fish for feeding and likely as a stopover site along their migratory routes (COUSSEAU et al., 2001; VALIÑAS et al., 2010). Temperature and salinity have been identified as important factors affecting the distribution of the main fish species within the Mar Chiquita coastal lagoon (GONZALEZ CASTRO et al., 2009). However, there is little information regarding the effect of weather variables coupled to water properties on the fish distribution.

The aim of this study was to assess the influence of environmental factors, such as water temperature, salinity and depth, as well as rainfall, wind direction and wind speed on both fish distribution and abundance in the Mar Chiquita coastal lagoon.

\section{Material and Methods}

\section{Sampling and Environmental Data}

Monthly fish samplings were carried out between February 1996 and January 1998 and then grouped by season. A total of 8 sampling stations (Fig. 1) were selected, distributed along the lagoon in three areas according to different environmental characteristics related to horizontal salinity range (COUSSEAU et al., 2001). Sampling station (St.) 1 (Channel 7 mouth) and St. 2 (San Antonio) corresponded to zone 1, with mixo-oligohaline water, little marine influence but a considerable contribution of freshwater from the streams and channels that flow into the lagoon. St. 3 (Punta Ondina), St. 4 (Punta Pejerrey), St. 5 (Galán) and St. 6 (Vuelta de Gómez) corresponded to zone 2, with mixo-mesohaline water, in the middle part of the lagoon. St. 7 (The Yacht Club) and St.8 (Mar Chiquita coastal lagoon mouth) corresponded to zone 3 , with mixo-eurihaline water and great marine influence. Sampling stations were taken as replicates of each zone of the lagoon. Because of logistical difficulties, zone 1 could not be sampled in winter 1996. 


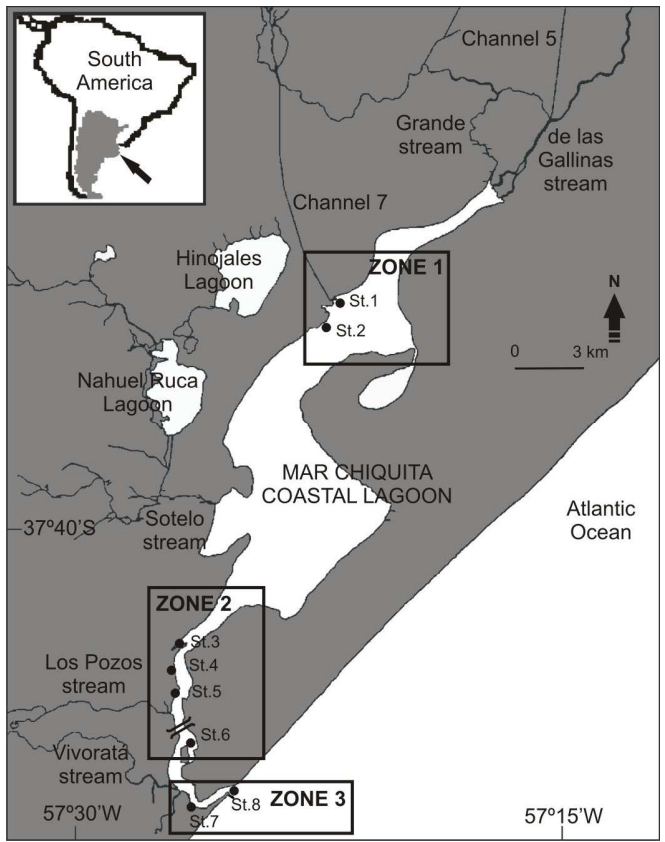

Fig. 1. Map of Mar Chiquita coastal lagoon with location of the sampling stations (St.). The inset shows the location of the study area in South America. St. 1: Channel 7 mouth, St. 2: San Antonio, St. 3: Punta Ondina, St. 4: Punta Pejerrey, St. 5: Galán, St. 6: Vuelta de Gómez, St. 7: The Yacht Club, St. 8: Mar Chiquita coastal lagoon mouth.

An $18 \mathrm{~m}$ long, $1.8 \mathrm{~m}$ wide nylon beach seine net with a $12 \mathrm{~mm}$ stretch mesh size and $4 \mathrm{~m}$ cod end was used to collect the samples during $3 \mathrm{~min}$ hauls parallel to the shoreline. Fish were identified to species level, counted and measured to the nearest $1 \mathrm{~mm}$ body length. The depth was recorded at each sampling station. Also water temperature (measured in ${ }^{\circ} \mathrm{C}$ ) and salinity (measured using the Practical Salinity Scale) were recorded using an alcohol thermometer and a Hydrobios refractometer, respectively. Rainfall, wind direction and wind speed were obtained from Mar Chiquita's Meteorological Davis Instruments Weather Monitor II model Station.

\section{Data Analysis}

To categorize the fish composition within the coastal lagoon, fish species were grouped in ecological categories (Table 1), following Whitfield (1998) and Moyle and Cech (2004), and classified as estuarine resident fish (ER) (those that inhabit estuarine waters throughout their life cycle), estuarine dependent marine fish (ED) (marine species which are predominantly found in lagoons at some stage of their life cycle), estuarine nondependent marine fish (EN) (species commonly found in both estuarine and coastal inshore areas and do not depend upon estuarine environment to complete their life cycles), occasional marine visitor fish $(\mathrm{OV})$ and freshwater fish (FW).

Fish abundance variability related to environmental factors was assessed using the generalized linear models (GLMs) (VENABLES; RIPLEY, 2002). For each ecological category, models were built with the number of fish captured as the response variable and the zone of the lagoon (zones 1 , 2 and 3), season (summer, autumn, winter and spring 1996 and 1997), temperature $\left({ }^{\circ} \mathrm{C}\right)$, salinity, depth (m), rainfall $(\mathrm{mm})$, wind direction and wind speed $\left(\mathrm{km} \mathrm{s}^{-1}\right)$ as independent variables. Since models had larger variance-mean relationships and many zero values characterized the samples, a negative binomial error distribution and a log link were specified (CRAWLEY, 2005). Model parameters were obtained by maximizing the maximum likelihood (CRAWLEY, 2005).

Each model consisted of possible combinations of the above indicated environmental factors. To select the model that best explained the abundance of a given ecological category, a multiplehypothesis model approach was used (FRANKLIN et al., 2001; JOHNSON; OMLAND, 2004). For each ecological category, the Akaike Information Criterion (AIC) of all the models considered was calculated and the model with the lowest AIC was selected as the best (FRANKLIN et al., 2001). Each model was weighed against the others using Akaike weights (w), which gives an estimation of the likelihood of the model's fit according to the data used (ANDERSON et al., 2000; FRANKLIN et al., 2001; JOHNSON; OMLAND, 2004).

\section{Results}

\section{Fish Composition and Ecological Categories}

Overall 30,068 individuals belonging to 16 families and 28 species were collected during the study period. The highest average abundance was recorded in zone 3 with $222.70( \pm 690.05)$ individuals while the lowest was recorded in zone 2 with $75.36( \pm$ 93.45) individuals.

Fifteen of the 28 species collected occurred in zone 1 (Table 1). Mugil liza and Odontesthes argentinensis were the only species collected in all the samples, the latter being the most frequent $(100 \% \mathrm{~F})$ and abundant $(130.42 \pm 168.17)$ in this area; followed by $M$. liza $(14.73 \pm 39.15)$, Brevoortia aurea $(6.24 \pm$ 28.75), Jenynsia multidendata (5.06 \pm 16.75$)$ and Micropogonias furnieri $(2.79 \pm 9.72)$. Other species present in this area rendered an average abundance of less than 1. The freshwater species Cnesterodon decemmaculatus, Oligosarcus jenynsii, Pimelodella laticeps and Rhamdia quelen were only present in this zone. 
Table 1. Species; ecological categories (EC): occasional marine visitor fish (OV), estuarine nondependent marine fish (EN), estuarine dependent marine fish (ED) and freshwater fish (FW); occurrance percentage (\%F); average abundance (Average ab.); size range as body length (Size rg.) and ontogenetic stage (Stg): juvenil (J) and adult (A) of fish collected by zone during the study period.

\begin{tabular}{|c|c|c|c|c|c|c|c|c|c|c|c|c|c|}
\hline \multirow[t]{2}{*}{ Species } & \multirow[t]{2}{*}{ EC } & \multicolumn{4}{|c|}{ ZONE 1} & \multicolumn{4}{|c|}{ ZONE 2} & \multicolumn{4}{|c|}{ ZONE 3} \\
\hline & & $\% \mathrm{~F}$ & $\begin{array}{l}\text { Average ab. } \\
(\text { mean } \pm \text { SD) }\end{array}$ & \begin{tabular}{|l} 
Size rg. \\
$(\mathrm{mm})$
\end{tabular} & Stg. & $\% \mathrm{~F}$ & $\begin{array}{l}\begin{array}{l}\text { Average ab. } \\
(\text { mean } \pm \text { SD) }\end{array} \\
\end{array}$ & \begin{tabular}{|l} 
Size rg. \\
$(\mathrm{mm})$
\end{tabular} & Stg. & $\% \mathrm{~F}$ & \begin{tabular}{|l}
$\begin{array}{l}\text { Average ab. } \\
(\text { mean } \pm \text { SD) }\end{array}$ \\
\end{tabular} & $\begin{array}{l}\text { Size rg. } \\
(\mathrm{mm})\end{array}$ & Stg. \\
\hline Anchoa marinii & $\mathrm{OV}$ & - & - & - & - & 0.91 & $0.01 \pm 0.09$ & 49 & $\mathrm{~J}$ & - & - & - & - \\
\hline $\begin{array}{l}\text { Lycengraulis } \\
\text { grossidens }\end{array}$ & ED & 3.03 & $0.03 \pm 0.17$ & 119 & J, A & 6.36 & $0.81 \pm 7.04$ & $30-135$ & J, A & 12.16 & $0.24 \pm 0.84$ & $47-225$ & J, A \\
\hline Brevoortia aurea & ED & 21.21 & $6.24 \pm 28.75$ & $35-85$ & $\mathrm{~J}$ & 48.18 & $18.93 \pm 42.11$ & $25-341$ & J, A & 67.57 & $\begin{array}{l}178.85 \pm \\
626.11 \\
\end{array}$ & $20-120$ & J, A \\
\hline Platanichthys platana & FW & 15.15 & $0.33 \pm 1.02$ & $34-70$ & $\mathrm{~A}$ & 14.55 & $1.00 \pm 3.82$ & $30-68$ & A & 29.73 & $3.88 \pm 9.86$ & $30-80$ & $\mathrm{~A}$ \\
\hline Ramnogaster arcuata & ED & - & - & - & - & 5.45 & $0.64 \pm 4.29$ & $40-70$ & A & 5.41 & $1.65 \pm 12.58$ & $40-58$ & A \\
\hline $\begin{array}{l}\text { Bryconamericus } \\
\text { iheringii }\end{array}$ & FW & 6.06 & $0.06 \pm 0.24$ & $58-69$ & A & 4.55 & $0.08 \pm 0.43$ & $54-72$ & A & 4.05 & $0.15 \pm 0.77$ & $51-91$ & A \\
\hline Cheirodon interruptus & FW & 3.03 & $0.03 \pm 0.17$ & 46 & $\mathrm{~A}$ & - & - & - & - & 1.35 & $0.01 \pm 0.12$ & 41 & $\mathrm{~A}$ \\
\hline $\begin{array}{l}\text { Hyphessobrycon } \\
\text { anisitsi }\end{array}$ & FW & 3.03 & $0.03 \pm 0.17$ & 67 & A & - & - & - & - & 1.35 & $0.03 \pm 0.23$ & 61-64 & A \\
\hline Oligosarcus jenynsii & FW & 6.06 & $0.24 \pm 1.23$ & $65-87$ & $\mathrm{~J}$ & - & - & - & - & - & - & - & - \\
\hline Rhamdia quelen & FW & 3.03 & $0.03 \pm 0.17$ & $54-88$ & $\mathrm{~J}$ & - & - & - & - & - & - & - & - \\
\hline Pimelodella laticeps & FW & 9.09 & $0.21 \pm 0.89$ & 87 & $\mathrm{~J}$ & - & - & - & - & - & - & - & - \\
\hline Mugil liza & ED & 54.55 & $14.73 \pm 39.15$ & $30-440$ & $\mathrm{~J}$ & 24.55 & $1.75 \pm 9.69$ & $24-543$ & $\mathrm{~J}, \mathrm{~A}$ & 24.32 & $1.86 \pm 5.88$ & $21-455$ & $\mathrm{~J}, \mathrm{~A}$ \\
\hline \begin{tabular}{|l} 
Odontesthes \\
argentinensis
\end{tabular} & ED & 100 & \begin{tabular}{|l|}
$130.42 \pm$ \\
168.17
\end{tabular} & $35-220$ & $\mathrm{~J}, \mathrm{~A}$ & 90 & $45.67 \pm 66.91$ & $40-320$ & $\mathrm{~J}, \mathrm{~A}$ & 81.08 & $32.55 \pm 75.96$ & $20-296$ & $\mathrm{~J}, \mathrm{~A}$ \\
\hline Odontesthes incisa & EN & - & - & - & - & 0.91 & $0.01 \pm 0.09$ & 83 & $\mathrm{~J}$ & 1.35 & $0.3 \pm 2.56$ & $70-95$ & $\mathrm{~J}$ \\
\hline Jenynsia multidentata & FW & 36.36 & $5.06 \pm 16.75$ & $18-75$ & $\mathrm{~A}$ & 7.27 & $0.07 \pm 0.26$ & $42-70$ & A & 5.41 & $0.07 \pm 0.30$ & $45-55$ & $\mathrm{~A}$ \\
\hline \begin{tabular}{|l|} 
Cnesterodon \\
decemmaculatus
\end{tabular} & FW & 3.03 & $0.03 \pm 0.17$ & 30 & A & - & - & - & - & - & - & - & - \\
\hline Diplectrum radiale & $\mathrm{OV}$ & - & - & - & - & - & - & - & - & 1.35 & $0.01 \pm 0.12$ & 39 & $\mathrm{~J}$ \\
\hline Dules auriga & OV & - & - & - & - & 0.91 & $0.01 \pm 0.09$ & 62 & $\mathrm{~J}$ & - & - & - & - \\
\hline Pomatomus saltatrix & OV & - & - & - & - & 0.91 & $0.01 \pm 0.09$ & 156 & $\mathrm{~J}$ & - & - & - & - \\
\hline Cynoscion guatucupa & EN & - & - & - & - & 2.73 & $0.04 \pm 0.23$ & 72-108 & $\mathrm{J}$ & 1.35 & $0.01 \pm 0.12$ & 35 & $\mathrm{~J}$ \\
\hline \begin{tabular}{|l} 
Menticirrhus \\
americanus
\end{tabular} & EN & - & - & - & - & 0.91 & $0.01 \pm 0.09$ & 158 & $\mathrm{~J}$ & - & - & - & - \\
\hline $\begin{array}{l}\text { Micropogonias } \\
\text { furnieri }\end{array}$ & ED & 9.09 & $2.79 \pm 9.79$ & $21-90$ & $\mathrm{~J}$ & 22.73 & $5.55 \pm 23.26$ & $35-110$ & $\mathrm{~J}$ & 35.14 & $1.53 \pm 4.01$ & $26-225$ & $\mathrm{~J}$ \\
\hline Pogonias cromis & ED & - & - & - & - & - & - & - & - & 1.35 & $0.03 \pm 0.23$ & $62-92$ & $\mathrm{~J}$ \\
\hline Umbrina canosai & EN & - & - & - & - & - & - & - & - & 1.35 & $0.04 \pm 0.35$ & $49-60$ & $\mathrm{~J}$ \\
\hline Australoheros facetus & FW & - & - & - & - & - & - & - & - & 1.35 & $0.01 \pm 0.12$ & 59 & A \\
\hline \begin{tabular}{|l|} 
Paralichthys \\
orbignyanus
\end{tabular} & ED & 24.24 & $0.3 \pm 0.59$ & $56-80$ & $\mathrm{~J}$ & 23.64 & $0.65 \pm 1.53$ & $30-400$ & $\mathrm{~J}, \mathrm{~A}$ & 31.08 & $0.77 \pm 1.49$ & $20-207$ & $\mathrm{~J}, \mathrm{~A}$ \\
\hline Oncopterus darwinii & ED & - & - & - & - & 2.73 & $0.05 \pm 0.28$ & 65-109 & $\mathrm{J}$ & 24.32 & $0.69 \pm 1.81$ & $25-132$ & $\mathrm{~J}$ \\
\hline Symphurus jenynsi & EN & - & - & - & - & 5.45 & $0.09 \pm 0.39$ & $45-95$ & $\mathrm{~J}$ & 1.35 & $0.01 \pm 0.12$ & 74 & $\mathrm{~J}$ \\
\hline
\end{tabular}

Eighteen of the 28 species collected occurred in zone 2. Odontesthes argentinensis was the most frequent $(90 \% \mathrm{~F})$ and abundant $(45.67 \pm$ 66.91), followed by Brevoortia aurea (18.93 \pm 42.11), Micropogonias furnieri (5.55 \pm 23.26$)$ and Mugil liza (1.75 \pm 9.69). Anchoa marinii, Dules auriga, Menticirrhus americanus, Oncopterus darwinii and Pomatomus saltatrix were only present in this zone.

A large number of species were recorded in zone 3 (20 of the 28 collected). Although Odontesthes argentinensis was the most frequent fish species in this area $(81.08 \% \mathrm{~F})$, Brevoortia aurea was the most abundant (178.85 \pm 626.11), followed by $O$. argentinensis $(32.55 \pm 75.96)$ and Platanichthys platana (3.88 \pm 9.86). Australoheros facetus, Diplectrum radiale, Pogonias cromis and Umbrina canosai were only present in this zone.

In terms of ecological categories, fish composition was dominated by ED species in all of the lagoon's three zones and in all the seasons of the year, and they accounted for $96.24 \%, 98.24 \%$ and 
$97.97 \%$ of the overall abundance of zones 1,2 and 3, respectively; followed by $\mathrm{FW}$ species, which accounted for $3.76 \%, 1.53 \%$ and $1.86 \%$ in each zone, respectively; EN species with $0.19 \%$ and $0.16 \%$ in zones 2 and 3, respectively and $\mathrm{OV}$ species with $0.03 \%$ and $0.01 \%$ in zones 2 and 3 , respectively. No ER species were collected during the study period. The two most important ecological categories were clearly dominated by few species: ED by Odontesthes argentinensis, Brevoortia aurea, Mugil liza and Micropogonias furnieri and FW by Platanichthys platana and Jenynsia multidentata.

\section{Environmental Factors}

A wide range of salinity values were observed in zones 2 and $3(2-33)$, while in zone 1 the salinity range was slighter $(0-5)$ (Fig. 2a). Water temperature values were in accordance with seasonal trends (Fig. 2b), with the highest values in warm months $\left(\max .26^{\circ} \mathrm{C}\right)$ and the lowest in cooler months $\left(\min .3^{\circ} \mathrm{C}\right)$. Rainfall was quite abundant during the spring months in both years. However, heavy rainfall characterized 1997, especially the winter months (Fig. 2c). Northerly winds predominated throughout the year with average speeds of 8 to $12 \mathrm{~km} \mathrm{~h}^{-1}$.

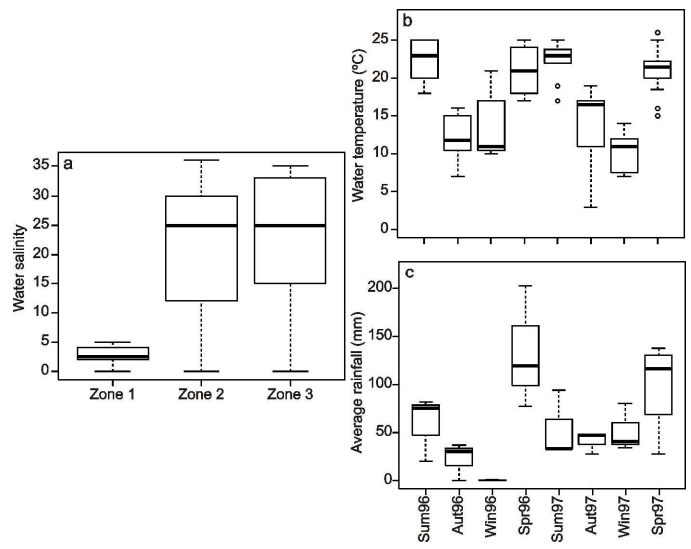

Fig. 2. Spatial variation in a) water salinity, and temporal variations in b) water temperature and c) water average rainfall in Mar Chiquita coastal lagoon during the study period.

\section{Ecological Categories in Relation to Environmental Factors}

Variation in ED abundance was related to spatial and temporal patterns. The model (AIC $=2$ $395.5 ; w=0.582$ ) which best explained this pattern included water temperature, season and zone sampled during the study period (Table 2). According to the model, the abundance of the ED category increased with water temperature in all three zones of the lagoon (Fig. 3). ED fish were abundant during summer and autumn in all three zones (Fig. 4). The most numerous species in this category were Brevoortia aurea, Odontesthes argentinensis, Mugil liza and Micropogonias furnieri. However, abundances of these species were higher in 1997 than in 1996. Brevoortia aurea, O. argentinensis and $M$. furnieri were the species which most contributed to the high abundance recorded in summer. Brevoortia aurea was the most abundant species in zone 3 and $O$. argentinensis in zones 1 and 2 .

Table 2. The best minimum model used to explain estuarine dependent marine fish (ED) species abundance distribution. The intercept and coefficient \pm standard error (SD) for the variables are given. $E_{i}$ : season of the year; $Z_{i}$ : zone of the lagoon; $T_{i}$ : water temperature.

\begin{tabular}{ccc}
\hline \hline Variable & Class variable & Coefficient \pm SD \\
\hline Intercept & & $4.879 \pm 0.437$ \\
$E_{i}$ & Aut97 & $0.674 \pm 0.344$ \\
& Spr96 & $-1.169 \pm 0.384$ \\
& Spr97 & $-0.549 \pm 0.392$ \\
& Sum96 & $-0.650 \pm 0.457$ \\
& Sum97 & $0.929 \pm 0.411$ \\
& Win96 & $-2.150 \pm 0.429$ \\
$Z_{i}$ & Win97 & $-0.086 \pm 0.342$ \\
& Zone2 & $-1.003 \pm 0.243$ \\
$T_{i}$ & Zone3 & $0.561 \pm 0.256$ \\
\hline
\end{tabular}

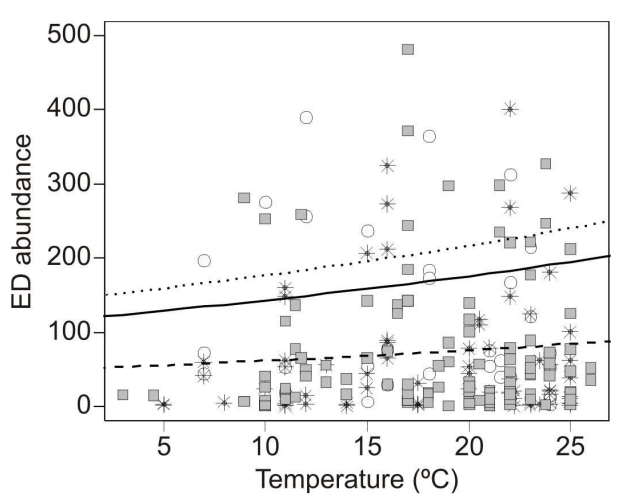

Fig. 3. ED species abundance related to water temperature and zones of Mar Chiquita coastal lagoon, estimated by a Generalized Linear Model with a log link and negative binomial error distribution. Solid line and open circle, zone 1; dashed line and gray solid square, zone 2; dotted line and asterisk, zone 3 .

The model $(\mathrm{AIC}=692.15 ; w=0.499)$ which best explained the FW species abundance distribution pattern included rainfall, wind direction, season and zone sampled during the study period (Table 3). According to the model, the abundance of FW rose as rainfall increased in all three zones of the lagoon, being greatest in zone 1 (Fig. 5a). A rise in abundance was also observed when easterly winds blew (Fig. 5b). Even though FW fish were more numerous in 1996, FW abundance was higher during the spring months in both years (Fig. 6). FW species were more abundant in the autumn than in the summer 
months of 1996, in contrast to what was observed in 1997. The most representative species of this category were Platanichthys platana and Jenynsia multidentata. The latter was highly abundant in 1997, while $P$. platana was more abundant in 1996. Jenynsia multidentata was the species which most contributed to the highest abundance of this category, observed in zone 1 , while $P$. platana was more abundant in zones 2 and 3 .

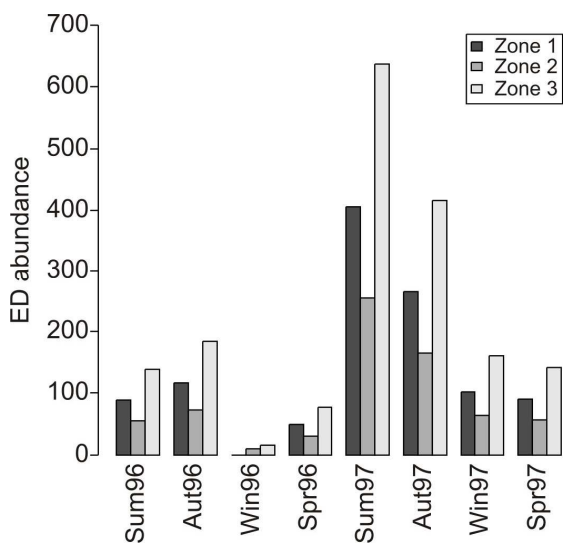

Fig. 4. ED species abundance related to seasons and zones of Mar Chiquita coastal lagoon, estimated by a Generalized Linear Model with a log link and negative binomial error distribution.

EN and OV species abundance distribution could not be modeled due to the fact that both categories together contributed less than $1 \%$ of the total catch. However, it was observed that the species of these two categories were more abundant in 1997. Most of these fish were more numerous during the warm spring-summer period with water temperatures of up to $16^{\circ} \mathrm{C}$, except for Odontesthes incisa which only entered the lagoon during the autumn months when water temperature were below $10^{\circ} \mathrm{C}$.

Table 3. The best model used to explain freshwater fish (FW) species abundance distribution. The intercept and coefficient \pm standard error (SD) for the variables are given. $E_{i}$ : season of the year; $Z_{i}$ : zone of the lagoon; $W_{i}$ : wind direction; $R_{i}$ : average rainfall.

\begin{tabular}{ccc}
\hline \hline Variable & Class variable & Coefficient \pm SD \\
\hline Intercept & & $4.609 \pm 0.957$ \\
$E_{i}$ & Aut97 & $-2.102 \pm 0.702$ \\
& Spr96 & $2.393 \pm 0.891$ \\
& Spr97 & $-1.665 \pm 0.745$ \\
& Sum96 & $-1.042 \pm 0.725$ \\
& Sum97 & $-2.824 \pm 0.779$ \\
& Win96 & $-1.856 \pm 1.002$ \\
$Z_{i}$ & Win97 & $-3.063 \pm 0.881$ \\
$W_{i}$ & Zone2 & $-2.635 \pm 0.468$ \\
& Zone3 & $-1.124 \pm 0.472$ \\
$R_{i}$ & North & $-2.249 \pm 0.781$ \\
& South & $-5.383 \pm 1.879$ \\
& West & $-2.259 \pm 0.984$ \\
& & $0.581 \pm 0.177$ \\
\hline
\end{tabular}
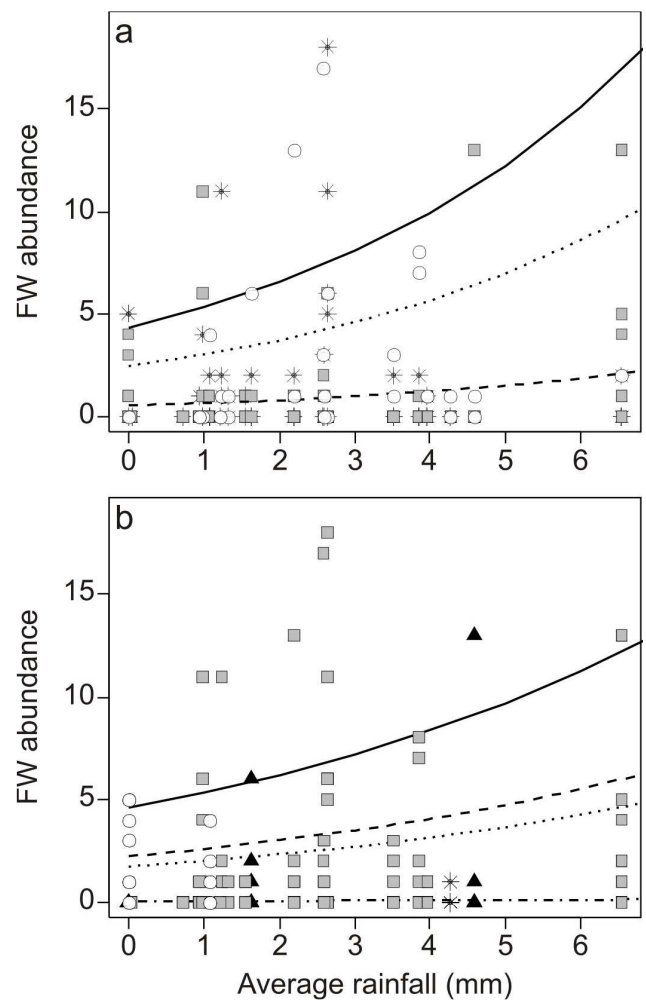

Fig. 5. FW species abundance related to average rainfall, wind direction and zones of Mar Chiquita coastal lagoon, estimated by a Generalized Linear Model with a log link and negative binomial error distribution. a) Solid line and open circle, zone 1; dashed line and gray solid square, zone 2; dotted line and asterisk, zone 3. b) Solid line and open circle, eastern wind; dashed line and black solid triangle, western wind; dotted line and gray solid square, northern wind; dot and dashed line and asterisk, southern wind.

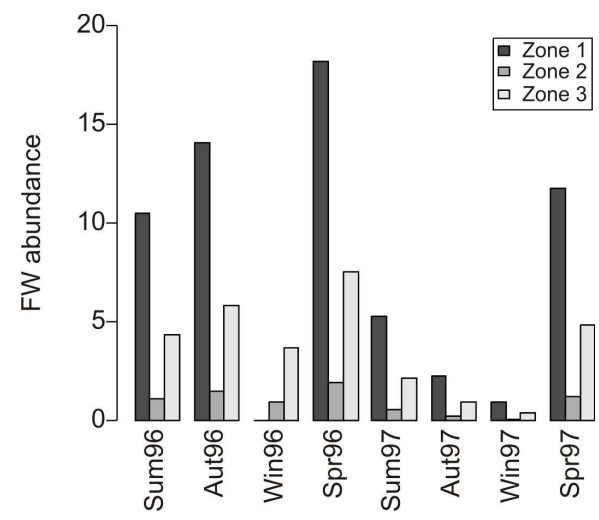

Fig. 6. FW species abundance related to seasons and zones of Mar Chiquita coastal lagoon, estimated by a Generalized Linear Model with a log link and negative binomial error distribution. 


\section{Discussion}

\section{Fish Composition and Ecological Categories}

The fish fauna of estuarine systems has long been regarded as dominated by estuarine-dependent or estuarine-opportunistic marine species, with ecological counterparts replacing particular species along a geographical latitudinal gradient (VIEIRA; MUSICK, 1994). During the study period, ED species clearly dominated the fish composition of Mar Chiquita coastal lagoon as had previously been observed in the study area (OLIVIER et al., 1972; COUSSEAU et al., 2001; GONZÁLEZ CASTRO et al. 2009), as well as in similar estuarine systems in Asia (AKIN et al., 2005), Africa (SIMIER et al., 2006; TREVOR; WHITFIELD, 2006), Europe (VEIGA et al., 2006) and South America (LOEBMANN et al., 2008). This feature may be due to a high tolerance to salinity variation (OLIVIER et al., 1972; JAUREGUIZAR et al., 2003; VEIGA et al., 2006). Although ED was the dominant category everywhere in the lagoon, mainly because of its four most numerous species, its highest abundance was observed in zone 3 , close to the mouth of the lagoon characterized by considerable marine water influence. Its abundance was twice that found in zone 2 and three times that of zone 1.

Brevoortia aurea was more abundant during the summer and autumn months. According to Cousseau and Perrota (2004), the species reproduces from late October to late December, and in January larvae and post larvae of between 15 and $20 \mathrm{~mm}$ remain on the coast of Mar del Plata city $(32 \mathrm{~km}$ southwest of Mar Chiquita). Juvenile and adult stages were collected during the study period, indicating the use of the lagoon as both nursery and feeding ground after reproduction.

Odontesthes argentinensis was more abundant during the warm spring-summer months, especially in zones 1 and 2, and larger sizes were present in zone 2. González Castro et al. (2009) found ripe and spent females in inner zones of the lagoon from winter months to spring months, suggesting possible reproductive events within the Mar Chiquita coastal lagoon.

Mugil liza was more abundant in zone 3, near to the mouth, during summer months, corroborating previous observations (ACHA, 1990; COUSSEAU et al., 2001). However, it was also collected in all three zones throughout the study period - with peaks in the spring months in zones 1 and 2.

Only juvenile stages of Micropogonias furnieri were collected in all three zones of the lagoon. Higher abundance of this species was recorded during summer months in zone 2. Only large sizes were collected in zone 3 . Reproduction occurs from spring to early summer (MACCHI, CHRISTIANSEN, 1992) and juveniles move into estuaries and streams from the sea (COUSSEAU; PERROTA, 2004). The low abundance found during winter may be due to the migration between the estuarine zone and the adjacent seawater, which begins in late autumn (HOZBOR; GARCÍA DE LA ROSA, 2000).

FW species abundance was higher in zone 1 , where the contribution of streams and channels is considerable and tide effect is insignificant (MARCOVECCHIO et al., 2006). The abundance of this category increased notably with heavier rainfall when the volume of the flow into the lagoon is great, and also when easterly winds blew. These abiotic effect factors are important during the spring and summer months when rainfall is at a maximum (RETA et al., 2001). Moreover, FW species were more abundant during the warm spring-summer months, thus corroborating the results of previous studies undertaken in similar environments (COUSSEAU et al., 2001; GARCIA et al., 2003; VEIGA et al., 2006). It was also observed that they were more abundant during 1996 than in 1997, in contrast to ED species. Although during 1997 heavy rainfall was reported, higher salinity water values were observed in zone 1 than had occurred in the previous year. This might indicate that some factor was restricting the discharge of continental water into the lagoon. Southwesterly or southeasterly winds limit the discharge of water from the lagoon into the sea (RETA et al., 2001) increasing the volume of water inside the lagoon and possibly reducing the discharge from the tributary streams. This would restrict the distribution of FW species inside the Mar Chiquita coastal lagoon. In contrast, Garcia et al. (2003) observed that FW species were more abundant than ED species during rainy years in Los Patos lagoon (Brazil).

\section{Ecological Categories Related to Environmental Factors}

The effects of water's physico-chemical properties on fish community distribution, abundance and composition in estuarine ecosystems have been studied by various authors in both temperate (YOUNG et al., 1997; PAPERNO; BRODIE, 2004) and tropical and subtropical environments (CASTILLO-RIVERA et al., 2002; BARLETTA et al., 2005; SIMIER et al., 2006), water temperature and salinity being the two main factors affecting fish distribution among and within estuarine environments. Moreover, Araújo and Costa de Acevedo (2001) have established that coastal lagoons present a marked stable salinity gradient, which is the main determinant of fishes' spatial distribution in these systems, acting directly on the osmotic potential of the organisms. No influence was observed, during this study, of water 
salinity on the fish abundance distribution model, whether for ED or FW species. In general, ED species were present throughout the lagoon. Although the larger number of FW species were collected in zone 1, where the lowest salinity values were registered, Platanichthys platana was the most abundant in terms of number of individuals in zone 3 , close to the mouth and where the highest water salinity values were recorded. The influence of Vivoratá stream in terms of water discharge to the coastal lagoon, as has been mentioned before, would allow the occurrence of FW species near the mouth of the lagoon. That was the case of the euryhaline-fish Bryconamericus iheringii and Jenynsia multidentata which have been recorded in this region and had also been mentioned previously in the study area (AZPELICUETA et al., 1998) and several Argentinian water bodies (MAC DONAGH, 1936; 1937). Therefore, the high abundance of both $B$. iheringii and $J$. multidentata in those zones with high salinity values would be masking the real behavior of this fish category, since the rest of the FW species were not collected in water with salinity values of above 5 .

Conversely, Paterson and Whitfield (2000) found that neither water salinity, nor temperature and turbidity were correlated with fish distribution in the Kariega estuary (South Africa), concluding that fish distribution is more closely correlated to water depth. In this study no contribution of water depth to the explanation of fish species distribution was found, probably due to the shallow depths registered in the lagoon. The average depth of zones 1 and 2 was between 0.8 and $0.9 \mathrm{~m}$. The little depth leads to the rapid mixing of the freshwater coming from tributary streams with that advected from the estuarine region (i.e. zone 3) to marine coastal water by means of wind action. Thus, salinity variation depends on tide characteristics, wind direction and intensity, and freshwater volume present in the lagoon (RETA et al., 2001). The brusque changes that characterize these environments (MOYLE; CECH, 2004) allow the occurrence of only those species capable of tolerating these particular physical events.

Thiel et al. (1995) found water temperature to be the best predictor of temporal changes in fish abundance and species composition in the Elbe estuary (Germany). Temperature has been identified as the primary abiotic factor controlling the key physiological, biochemical and life-history processes of fish (BEITINGER; FITZPATRICK, 1979), and has been found to influence the utilization of estuaries by fishes worldwide (THIEL et al., 1995; HARRISON; WHITFIELD, 2006). Generally, fish have a thermal preference that optimizes physiological processes (SELLESLAGH; AMARA, 2008). Here, this variable ranged according to a seasonal trend as has been mentioned previously by Reta et al. (2001), who observed that mean water temperature values correlated to the air temperature thermal cycle and weather conditions. It was also observed that in the Mar Chiquita coastal lagoon shallow depth allows more rapid thermal changes in response to changing weather conditions than occur in deeper waters offshore. Water temperature was an important factor in the ED species distribution model. It was observed that fish abundance increased with temperature during spring-summer months, thus corroborating previous results obtained in similar environments (SUDA et al., 2002; GARCIA et al., 2003; FRANCO et al., 2006; POMBO et al., 2005; VEIGA et al., 2006). This event has been mainly attributed to the arrival of marine prejuvenile specimens of species that spawn in late winter-early spring. High abundance of adult stages was also recorded during these periods of the year, which may be due to migration into the Mar Chiquita coastal lagoon for feeding purposes once reproduction has taken place.

According to the size range capture, eight ED species of the nine collected were represented by juveniles. This emphasizes the importance of this ecosystem as a nursery ground where fish find suitable conditions for their development (VEIGA et al., 2006), better feeding conditions, optimal growth, refuge and high connectivity with other habitats (BECK et al., 2001). However, little is known about the patterns of use of this coastal lagoon by fish in their early life stages such as would give us a better understanding of the role of the lagoon in fishes' life history, a question into which further investigation should be encouraged.

The presence of EN and OV fishes seemed to depend on weather conditions that favor the intrusion of great volumes of sea water, as has previously been observed in the study area (GONZÁLEZ CASTRO et al., 2009) where several species of both categories have been found near the mouth of the lagoon with high water salinity values.

Results obtained during this study established that a differential habitat use by species that occur in the lagoon is found. Few ED species dominate the fish composition. One group consists of those fish species (e.g. Odontesthes argentinensis) capable of swimming towards inner areas with mixooligohaline waters. On the other hand, some fish species (e.g. Brevoortia aurea) remain near the lagoon's outlet to the sea. FW species make use of the lagoon under conditions of heavy rainfall when freshwater drainage occurs but only in areas where tidal action is barely noticeable. However, several other potential factors involved in structuring fish assemblage distribution within estuarine environments, such as food availability (KNEIB, 1997), dissolved oxygen and turbidity (GARCIA et 
al., 2003; POMBO et al., 2005) or biological interactions (group behavior, competition and predation) (MARTINO; ABLE, 2003), should be considered in further studies.

\section{AcKNOWLEDGMenTS}

We express our gratitude to J. Mangiarotti (forest guard of Mar Chiquita Biosphere Reserve) for sampling permission and to M. B. Cousseau, J. Hansen, A. M. Vanin and anonymous reviewers for their helpful comments on early drafts of this MS. D.O.B. was supported by a scholarship from Consejo Nacional de Investigaciones Científicas y Técnicas (CONICET, Argentina). This is INIDEP contribution no. 1761.

\section{REFERENCES}

ACHA, E. M. Estudio anatómico-ecológico de la lisa (Mugil liza) durante su primer año de vida. Frente Marit., v. 7 , n. A, p. 37-43, 1990.

AKIN, S.; BUHAN, E.; WINEMILLER, K. O.; YILMAZ, H. Fish assemblage structure of Koycegiz lagoon-estuary, Turkey: Spatial and temporal distribution patterns in relation to environmental variation. Estuar. Coast. Shelf Sci., v. 64, p. 671-684, 2005.

ANDERSON, D. R.; BURNHAM, K. P.; THOMPSON, W. L. Null hypothesis testing: problems, prevalence, and alternative. J. Wildl. Manage., v. 64, p. 912-923, 2000.

ARAUJO, F. G.; COSTA DE AZEVEDO, M. C. Assemblages of the southeast-south Brazilian coastal systems based on the distribution of fishes. Estuar. Coast. Shelf Sci., v. 52, p. 729-738, 2001.

AZPELICUETA, M. M.; FIGUEROA, D. E.; DÍAZ DE ASTARLOA, J. M.; COUSSEAU, M. B. Freshwater fishes in a world reserve of biosphere: Mar Chiquita coastal lagoon (Buenos Aires, Argentina). Biogeographica, v. 74, p. 85-90, 1998.

BARLETTA, M.; BARLETTA-BERGAN, A.; SAINTPAUL, U.; HUBOLD, G. The role of salinity in structuring the fish assemblage in a tropical estuary. $\mathbf{J}$. Fish Biol., v. 66, p. 45-72, 2005.

BECK, M. W.; HECK, K. L.; ABLE, K. W.; CHILDERS, D. L.; EGGLESTON, D. B.; GILLANDERS, B. M.; HALPERN, B.; HAYS, C. G.; HOSHINO, K.; MINELLO, T. J.; ORTH, R. J.; SHERIDAN, P. F.; WEINSTEIN, M. P. A better understanding of the habitats that serve as nurseries for marine species and the factors that create site-especific variability in nursery quality will improve conservation and management of these areas. BioScience, v. 51, p. 633-641, 2001.

BEITINGER, T. L.; FITZPATRICK, L. C. Physiological and ecological correlates of preferred temperature in fish. Am. Zool., v. 19, p. 319-330, 1979.

BLABER, S. J. M. Tropical estuarine fishes. Ecology, exploitation and conservation. Oxford: Blackwell Science, 2000. 372 p.
BLABER, S. J. M.; BLABER, T. G. Factors affecting the distribution of juvenile estuarine and inshore fish. J. Fish Biol., v. 17, p. 143-162, 1980.

CASTILLO-RIVERA, M.; ZAVALA-HURTADO, J. A.; ZARATE, R. Exploration of spatial and temporal patterns of fish diversity and composition in a tropical estuarine system of Mexico. Rev. Fish Biol. Fish., v. 12, p. 167-177, 2002.

COUSSEAU, M. B.; PERROTA, R. G. Peces marinos de Argentina: Biología, distribución, pesca. $3^{\text {th }}$. ed. Mar del Plata: INIDEP, 2004. 167 p.

COUSSEAU, M. B.; DÍAZ DE ASTARLOA, J. M.; FIGUEROA, D. E. La Ictiofauna de la Laguna Mar Chiquita. In: IRIBARNE, O. (Ed.) Reserva de Biósfera Mar Chiquita: Características físicas, biológicas y ecológicas. Mar del Plata: Editorial Martín, 2001. p. 187203.

CRAWLEY, M. J. Statistics: an introduction using R. $1^{\text {st }}$. ed.Chichester: Wiley, 2005. 327 p.

DAY, J. W. J.; YAÑEZ-ARANCIBIA, A. Coastal lagoons and estuaries as an environmental nekton. In: YAÑEZARANCIBIA (Ed.) Fish Community ecology in estuaries and coastal lagoons: towards an ecosystem integration. México: UNAM, Press, 1985. p. 17-34.

ELLIOT, M.; HEMINGWAY, K. L. Fishes in estuaries. $2^{\text {nd }}$. ed. Oxford: Blackwell Science, 2002. 636 p.

FRANCO, A.; FRANZOI, P.; MALAVASI, S.; RICCATO, F.; TORRICELLI, P.; MAINARDI, D. Use of shallow water habitats by fish assemblages in a Mediterranean coastal lagoon. Estuar. Coast. Shelf Sci., v. 66, p. 6783, 2006.

FRANKLIN, A. B.; SHENK, T.M.; ANDERSON, D.R.; BURNHAM, K. P. Statistical model selection: an alternative to null hypothesis testing. In: SHENK, T. M.; FRANKLIN, A. M. (Eds.) Modeling in natural resources management: development, interpretation, and application. Washington: Island Press, 2001. p. 7590

GALVÁN-PIÑA, V. H.; GALVÁN-MAGAÑA, F.; ABITIACÁRDENAS, L. A.; GUTIÉRREZ-SÁNCHEZ, F. J.; RODRIGUEZ-ROMERO, J. Seasonal structure of fish assemblages in rocky and sandy habitats in Bahía de la Paz, Mexico. Bull. Mar. Sci., v. 72, n. 1, p. 19-35, 2003.

GARCIA, A. M.; VIEIRA, J. P.; WINEMILLER, K. O. Effects of 1997-1998 El Niño on the dynamics of the shallow-water fish assemblage of the Patos Lagoon estuary (Brazil). Estuar. Coast. Shelf Sci., v. 57, p. 489$500,2003$.

GIBSON, R. N. Impact of habitat quality and quantity on the recruitment of juvenile flatfishes. Neth. J. Sea Res., v. 32, p. 191-206, 1994.

GONZÁlEZ CASTRO, M.; DÍAZ DE ASTARLOA, J. M.; COUSSEAU, M. B.; FIGUEROA, D. E.; DELPIANI, S. M.; BRUNO, D. O.; GUZONNI, J. M.; BLASINA, G. E.; DELI ANTONI, M. Y. Fish composition in a southwestern Atlantic temperate coastal lagoon: Spatialtemporal variation and relationships with environmental variables. J. Mar. Biol. Assoc. UK., v. 89, n. 3, p. 593604, 2009.

HARRISON, T. D.; WHITFIELD, A. K. Temperature and salinity as primary determinants influencing the biogeography of fishes in South African estuaries. Estuar. Coast. Shelf Sci., v. 66, p. 335-345, 2006 
HOZBOR, N. M; GARCIA DE LA ROSA, S. B. Alimentación de juveniles de corvina rubia (Micropogonoas furnieri) en la laguna costera Mar Chiquita (Buenos Aires, Argentina). Frente Marit., v. 18, n. A, p. 59-70, 2000.

IRIBARNE, O.; BORTOLUS, A.; BOTTO, F. Betweenhabitat differences in burrow characteristics and trophic modes in the southwestern Atlantic burrowing crab Chasmagnathus granulata. Mar. Ecol. Prog. Ser., v. 155, p. 137-145, 1997

ISACCH, J. P.; COSTA, C. S. B.; RODRIGUEZGALLEGO, L.; CONDE, D.; ESCAPA, M. GAGLIARDINI, D. A.; IRIBARNE, O. O. Distribution of saltmarsh plant communities associated with environmental factors along a latitudinal gradient on the SW Atlantic coast. J. Biogeogr., v. 33, p. 888-900, 2006.

ISLA, F. I. 1995. Coastal Lagoons. In: PERILLO, G. M. E. (Ed.) Geomorfology and Sedimentology of estuaries. Amsterdam: Elsevier Science, 1995. v. 53, p. 241-272. (Developments in Sedimentology).

JAUREGUIZAR, A. J.; MENNI, R.; BREMEC, C.; MIANZAN, H.; LASTA, C. Fish assemblage and environmental patterns in the Río de la Plata estuary. Estuar. Coast. Shelf Sci., v. 56, p. 921-933, 2003.

JOHNSON, J. B.; OMLAND, K. S. Model selection in ecology and evolution. Trends Ecol. Evol., v. 19, p. 101-108, 2004.

KJERFVE, B.; MAGILL, K. E. Geographic and hydrodynamic characteristics of shallow coastal lagoons. Mar. Geol., v. 88, p. 187-199, 1989.

KNEIB, R. T. Early life stages of resident nekton in intertidal marshes. Estuaries, v. 20, n. 1, p. 214-230, 1997.

LOEBMANN, D.; VIEIRA, J. P.; AZEVEDO, M. B. DE; DÍAZ DE ASTARLOA, J. M.; COUSSEAU, M. B.; FIGUEROA， D. E. Composição e abundância da ictiofauna de duas lagunas costeiras da América do Sul Austral: lagoa do Peixe $\left(31^{\circ} \mathrm{S} ; 51^{\circ} \mathrm{W}\right)$, Brasil e laguna Mar Chiquita $\left(37^{\circ} \mathrm{S} ; 57^{\circ} \mathrm{W}\right)$, Argentina. Neo. Biol. Conserv., v. 3, n. 1, p. 28-33, 2008.

MAC DONAGH, E. J. Sobre peces del territorio del río Negro. Notas Museo de La Plata. Zoología, v. 1, p. $403-$ $422,1936$.

MAC DONAGH, E. J Estudios zoológicos en el río Negro inferior. Revta Mus. d La Plata, v. Sección Oficial 1936, p. 166-174, 1937.

MACCHI, G. J.; CHRISTIANSEN, H. E. Estudio histológico del ciclo reproductivo en hembras de la corvina rubia (Micropogonias furnieri). Análisis de la estructura madurativa en distintas localidades del area bonaerense. Frente Marit., v. 11, p. 47-56, 1992.

MARCOVECCHIO, J.; FREIJE, H.; DE MARCO, S.; GAVIO, A.; FERRER, L.; ANDRADE, S.; BELTRAME, O.; ASTEASUAIN, R. Seasonality of hydrographic variables in a coastal lagoon: Mar Chiquita, Argentina. Aquatic Conserv: Mar. Freshw. Ecosyst., v. 16, n. 4, p. 335-347, 2006.

MARSHALL, S.; ELLIOTT, M. Environmental influences on the fish assemblage of the Humber estuary, U.K. Estuar. Coast. Shelf Sci., v. 46, p. 175-184, 1998.

MARTINO, E. J.; ABLE, K. W. Fish assemblages across the marine to low salinity transition zone of a temperate estuary. Estuar. Coast. Shelf Sci., v. 56, p. 969-987, 2003.
MOYLE, P.; CECH Jr., J. J. Fishes. An introduction to Ichthyology. $5^{\text {th }}$. ed. London: Prentice Hall International (UK), 2004. 726 p.

OLIVIER, S. R.; ESCOFET, A. M.; PENCHASZADEH, P.; ORENSANZ, J. M. Estudios ecológicos de la región estuarial de Mar Chiquita (Buenos Aires). I Comunidades bentónicas. Anal. Soc. Cient. Arg., v. 193, p. 237-262, 1972.

PAPERNO, R.; BRODIE, R. B. Effects of environmental variables upon the spatial and temporal structure of a fish community in a small, freshwater tributary of the Indian River Lagoon, Florida. Estuar. Coast. Shelf Sci., v. 61, p. 229-241, 2004.

PATERSON, A. W.; WHITFIELD, A. K. Do shallow-water habitats function as refugia for juvenile fishes? Estuar. Coast. Shelf Sci., v. 74, p. 263-273, 2000

POMBO, L.; ELLIOT, M.; REBELO, J. E. Environmental influences on fish assemblage distribution of an estuarine coastal lagoon, Ria de Aveiro (Portugal). Sci. Mar., v. 69, n. 1, p. 143-159, 2005.

RETA, R.; MARTOS, P.; PERILLO, G. M. E.; PICCOLO, M. C.; FERRANTE, A. Características hidrográficas del estuario de la laguna Mar Chiquita. In: IRIBARNE, O. (Ed.). Reserva de Biósfera Mar Chiquita: Características físicas, biológicas y ecológicas. Mar del Plata: Editorial Martín, 2001. p. 31-52.

SELLESLAGH, J.; AMARA, R. Environmental factors structuring fish composition and assemblages in a small macrotidal estuary (eastern English Channel). Est. Coast. Shelf Sci., v. 79, n. 3, p. 507-517, 2008.

SIMIER, M.; LAURENT, C.; ECOUTIN, J. M.; ALBARET, J. J. The Gambia River estuary: A reference point for estuarine fish assemblages studies in West Africa. Estuar. Coast. Shelf Sci., v. 69, p. 615-628, 2006.

SUDA, Y.; INOUE, T.; UCHIDA, H. Fish communities in the surf zone of a protected sandy beach at Doigahama, Yamaguchi Prefecture, Japan. Estuar. Coast. Shelf Sci., v. 55, p. 81-96, 2002.

THIEL, R.; SEPULVEDA, A.; KAFEMAN, R.; NELLEN, W. Environmental factors as forces structuring the fish community of the Elbe estuary. J. Fish Biol., v. 46, p. 47-69, 1995.

TREVOR, D. H.; WHITFIELD, A. K. Estuarine typology and the structuring of fish communities in South Africa. Environ. Biol. Fish., v. 75, p. 269-293, 2006.

UNESCO. Nine new biosphere reserves designated by the MAB bureau. Biosphere Reserves: Bull. World Network, v. 4, p. 6-10, 1996.

VALIÑAS, M.; ACHA, E. M.; IRIBARNE, O. Habitat use and feeding habits of juvenile fishes in an infrequently flooded Atlantic saltmarsh. Mar. Fresh. Res., v. 61, p. 1154-1163, 2010.

VENABLES, W. N.; RIPLEY, B. D. Modern applied statistics with S-Plus. $4^{\text {th }}$. ed. New York: Springer, 2002. 584 p.

VEIGA, P.; VIEIRA, L.; BEXIGA, C.; SÁ, R.; ERZINI, K. Structure and temporal variations of fish assemblages of the Castro Marim salt marsh, sourthern Portugal. Estuar. Coast. Shelf Sci., v. 70, p. 27-38, 2006.

VIEIRA, J. P.; MUSICK, J. A. Fish faunal composition in warm-temperate and tropical estuaries of Western Atlantic. Atlântica, v. 16, p. 31-53, 1994. 
WHITFIELD, A. K. Biology and ecology of fishes in southern African estuaries. Grahamstown: Ichthyological Monograph of the J.L.B. Smith Institute of Ichthyology 1998. v. 2, 223 p.

WHITFIELD, A. K. Ichthyofaunal assemblages in estuaries: A South African case study. Rev. Fish Biol. Fish., v. 9 , p. 151-186, 1999.

YOUNG, G. C.; POTTER, L. C.; HYNDES, G. A.; DE LESTANG, S. The ichthyofauna of an intermittently open estuary: implications of bar breaching and low salinities on faunal composition. Estuar. Coast. Shelf Sci., v. 45, p. 53-68, 1997.

(Manuscript received 09 July 2012; revised 03 February 2013; accepted 04 February 2013) 